\title{
The Chemical Mechanism of the Formation of Fluorite-Barite-Siderite Carbonatite in Karasug Fe-F-Ba-Sr-REE Deposit
}

\author{
Alexander V. Bolonin \\ Institute of Geology of Ore Deposits, Petrography, Mineralogy and Geochemistry, RAS, Moscow, Russia \\ Email: bolonin.a@inbox.ru
}

How to cite this paper: Bolonin, A.V. (2018) The Chemical Mechanism of the Formation of Fluorite-Barite-Siderite Carbonatite in Karasug Fe-F-Ba-Sr-REE Deposit. Open Journal of Geology, 8, 399-403. https://doi.org/10.4236/ojg.2018.84023

Received: February 28, 2018

Accepted: April 10, 2018

Published: April 13, 2018

Copyright $\odot 2018$ by author and Scientific Research Publishing Inc. This work is licensed under the Creative Commons Attribution International License (CC BY 4.0).

http://creativecommons.org/licenses/by/4.0/

\begin{abstract}
Intrusive fluorite-barite-siderite carbonatite of Karasug deposit (Tuva) crystallized from ionic salt melt is dominated by iron chloride with the participation of alkali metal salts. Melt composition and main reaction of mineral formation: $\mathrm{NaFeCl}_{3}+4 \mathrm{KF}+2 \mathrm{Na}_{2} \mathrm{Ca}\left(\mathrm{CO}_{3}\right)_{2}+\mathrm{Na}_{2} \mathrm{Ba}\left(\mathrm{CO}_{3}\right)_{2}+\mathrm{Na}_{2} \mathrm{SO}_{4}=6 \mathrm{FeCO}_{3}+$ $2 \mathrm{CaF}_{2}+\mathrm{BaSO}_{4}+14 \mathrm{NaCl}+4 \mathrm{KCl}$. The highest temperature $\left(550^{\circ} \mathrm{C}-650^{\circ} \mathrm{C}\right)$ brine-melt inclusions in minerals are pseudo-primary. Their predominant $\mathrm{Na}-\mathrm{K}$-chloride composition does not correspond to the primary melt, but is close to the residual brine-melt.
\end{abstract}

\section{Keywords}

Ferrocarbonatite Ionic Melt, Chemical Reactions

\section{Introduction}

Karasug Fe-F-Ba-Sr-REE deposit is located in the Republic of Tuva (Russia). Carbonatite type of the deposit and intrusive genesis of carbonatites on the basis of geological and mineralogical data are proved in literature [1] [2]. Recently obtained thermobarogeochemical data on the composition of primary mineral-forming inclusions in minerals [3] do not fully agree with the idea of the intrusive genesis of carbonatites. In this work, an attempt is made to link the existing geological, mineralogical and thermobarogeochemical data with each other in order to decode the primary composition of the ferrocarbonatite melt, the form of finding petrogenic components and probable chemical reactions of mineral formation.

Rare-earth fluorite-barite-siderite carbonatites form the basis of multicomponent ores of the deposit. They compose bodies of pipe- and dike-shaped form, 
with a size of tens or hundreds of meters. The primary composition of carbonatites includes (average wt.\%): siderite-61, barite and barytocelestite-20, fluorite -12 , pyrite -3 , bastnaesite -1.5 , quartz -1 , apatite -0.5 ; permanent accessory minerals-monazite, uraninite, molybdenite, rutile; sporadic mineralsmagnetite, ankerite, ferrous muscovite, microcline. Siderite contains relatively few impurity components (wt.\%): $\mathrm{MnO}-1.1, \mathrm{MgO}-1.0, \mathrm{CaO}-0.7, \mathrm{SrO}-0.1$. Carbonatites are characterized by porphyritic structure: idiomorphic crystals of $0.5-10 \mathrm{~mm}$ size of siderite, fluorite, barite, pyrite, quartz and bastnaesite are surrounded by fine-grained $(<0.2 \mathrm{~mm})$ fluorite-siderite groundmass. Carbonatites have a massive or directional texture, and contain angular fragments of host sandstones and granitoids, almost without having a metasomatic effect on them.

Comprehensive thermobarogeochemical study of melt and fluid inclusions in phenocrysts of cubic fluorite and hexagonal-dipyramidal quartz was made in recent years [3]. Brine-melt inclusions of $15-80 \mu \mathrm{m}$ in size are referred to the primary category. They consist of solid salt phases (87 - $92 \mathrm{wt} . \%)$, liquid water-salt solution $(10 \%-6 \%)$ and liquid $\mathrm{CO}_{2}(2 \%-3 \%)$. The solid phases are represented by halite ( $45 \%-48 \%)$ and silvin $(32 \%-30 \%)$. In addition to them in different vacuoles were observed up to five different phases, among which diagnosed: carbonates-siderite (up to $10 \%$ - 15\%), ankylite bastnaesite; sulfatesanhydrite, barytocelestite, ferricopiapite; ore minerals-galena, hematite. The temperature of homogenization of inclusions is $550^{\circ} \mathrm{C}-650^{\circ} \mathrm{C}$, and the pressure is estimated at $290-360 \mathrm{MPa}$.

\section{Discussion}

Attention is drawn to the fact that in the composition of brine-melt inclusions, there are few components that make up the material basis of carbonatites$\mathrm{CO}_{3}{ }^{2-}, \mathrm{Fe}, \mathrm{Ba}, \mathrm{Sr}, \mathrm{F}, \mathrm{S}$. In total, they do not exceed $12-16$ wt.\%. Mineral formation from such matter cannot flow magma way, that is by close simultaneous crystallization in a stable volume of introduced melt. It is necessary to flow a multiple volume of matter through the crystallization zone by the mechanism of the hydrothermal system. It can be assumed that the studied inclusions are pseudo-primary. Their composition does not correspond to the primary melt, but, as will be shown below, corresponds to the residual brine-melt. We will try to reconstruct hypothetically the probable chemical composition of the primary melt, from which fluorite-barite-siderite carbonatites were formed, as well as identify the problems that arise. Two variants of the composition are discussed below. In both cases, following [4] [5] carbonatite melt is considered to be an ionic liquid, fundamentally different from structured and polymerized silicate melts.

The first option: The primary magma is a congruent melt of the components that make carbonatite: $\mathrm{FeCO}_{3}+\mathrm{CaF}_{2}+(\mathrm{Ba}, \mathrm{Sr}) \mathrm{SO}_{4}$. This melt fills and mineralizes the entire body volume of carbonatites as a result of a single act of introduction and two-stage crystallization (phenocrysts-the groundmass). This 
mechanism of formation matches the observed features of the structure subvolcanic carbonatites-porphyritic structure, fluid type directional and banded textures, autolith breccias, cataclastic phenocrysts.

Experiments on melting in system $\mathrm{CaCO}_{3}(31.2 \%)-\mathrm{Ca}(\mathrm{OH})_{2}(24.9 \%)-\mathrm{CaF}_{2}(13.5 \%)-\mathrm{BaSO}_{4}(10.4 \%)-\mathrm{La}(\mathrm{OH})_{3}(20.0 \%)$ is received glass at $T=650^{\circ} \mathrm{C}$ and $P=100 \mathrm{MPa}$ [6]. This proves the existence of the calcite-fluorite-barite melt under relatively low $P$ - $T$ conditions that are acceptable for subvolcanic carbonatites. However, siderite, in comparison with calcite, has a very low temperature of thermal dissociation $490^{\circ} \mathrm{C}$ at atmospheric pressure. Experiments that would show the stability of iron carbonate in magmatic conditions are unknown to the author.

The second option: The primary magma is represented by an ionic salt melt, in which in addition to rock-forming elements $(\mathrm{Fe}, \mathrm{Ba}, \mathrm{Sr}, \mathrm{Ca}, \mathrm{O}, \mathrm{C}, \mathrm{S}, \mathrm{F})$ there are low-melting salts of alkali metals. This is directly indicated by the dominance of chlorides $\mathrm{Na}$ and $\mathrm{K}$ in the studied inclusions.

It is possible to specify the most probable chemical form of finding the main components in the melt. Iron in high-temperature conditions forms a compound with chlorine in the form of $\mathrm{NaFeCl}_{3}, \mathrm{KFeCl}_{3}$ [7]. Calcium in experimental and natural melts (lava of current African volcano Oldoinyo-Lengai) is in the form of double salts of the type $\mathrm{Na}_{2} \mathrm{Ca}\left(\mathrm{CO}_{3}\right)_{2}, \mathrm{~K}_{2} \mathrm{Ca}\left(\mathrm{CO}_{3}\right)_{2}$ [5]. In the same compounds may be other alkaline earth elements-barium and strontium. Sulfur and fluorine form low-melting salts- $\mathrm{K}_{2} \mathrm{~S}, \mathrm{Na}_{2} \mathrm{SO}_{4}, \mathrm{NaF}, \mathrm{KF}$.

A large number of sulfate in carbonatites ( $20 \mathrm{wt} . \%)$ indicates a significant transition of primary sulphide sulfur to sulphate. Only partly the appearance of sulfate ion can be explained by the interaction of the melt with volatile components: $\mathrm{K}_{2} \mathrm{~S}+2 \mathrm{NaF}+\mathrm{CO}_{2} \uparrow+2 \mathrm{H}_{2} \mathrm{O} \uparrow=\mathrm{Na}_{2} \mathrm{SO}_{4}+2 \mathrm{KF}+\mathrm{CH}_{4} \uparrow \quad$ (gas is indicated by an arrow, the liquid phase is without indication). Most likely, there was a sharp increase in the oxidative potential due to an external oxygen source, although its nature and method of penetration into the high-pressure magmatic system remain unclear.

To crystallize the main rock-forming minerals (siderite, fluorite and barite) from the melt, ionic exchange reactions of the type are sufficient:

$$
\begin{aligned}
& 6 \mathrm{NaFeCl}_{3}+4 \mathrm{KF}+2 \mathrm{Na}_{2} \mathrm{Ca}\left(\mathrm{CO}_{3}\right)_{2}+\mathrm{Na}_{2} \mathrm{Ba}\left(\mathrm{CO}_{3}\right)_{2}+\mathrm{Na}_{2} \mathrm{SO}_{4} \\
& =6 \underline{\mathrm{FeCO}}_{3}+2 \underline{\mathrm{CaF}}_{2}+\underline{\mathrm{BaSO}}_{4}+14 \mathrm{NaCl}+4 \mathrm{KCl} \text { (solid phase is underlined). }
\end{aligned}
$$

In this chemical reaction, the coefficients are chosen so that the molar ratio of minerals in the reaction products corresponds to their weight ratio in carbonatites. The reaction shows that the predominance of iron chloride in the primary melt ensures the binding of alkaline elements in the chemically non-aggressive chloride form. This may explain the absence in Karasug ore field of alkali metasomatism of host rocks, which is typical for many carbonatite complexes in the world. From the same reaction it follows that the residual chloride melt is much larger in volume than the crystalline phase. The author does not find an answer to the questions: how and where a huge amount of $\mathrm{Na}-\mathrm{K}$ chlorides could be 
removed from the crystallizing melt and how this is reflected in the morphology and structure of carbonatites?

It is obvious that the residual chloride melt concentrated fluid components and contained the remains of rock-forming elements. To such brine investigated inclusions in minerals from fluorite-barite-siderite carbonatites are close. Pseudo-primary nature of the inclusions can be explained by the fact that crystallization occurs through ionic exchange reactions. In this case, the growing mineral in the boundary layer is constantly surrounded by a film of liquid reaction products, which are $\mathrm{Na}$ and $\mathrm{K}$ chlorides. Together with the fluid, they could be preserved in inclusions under the condition of a delayed inflow of fresh portions of the melt to the boundary layer. Such a condition may be feasible in a relatively viscous salt melt (in comparison with a hydrothermal solution).

In real conditions of carbonatite formation there may be a combination of the above two options. The main rock-forming components are present partially in the form of eutectic melting directly $\mathrm{CaF}_{2}, \mathrm{BaSO}_{4}$ and $\mathrm{FeCO}_{3}$, and partly in the form of fusible salts in connection with alkaline metals. It is assumed saturation of the melt with volatile components, as evidenced by a large share of gas-liquid phase in crystal-fluid inclusions and explosive brecciation during the formation of the carbonatite bodies.

At the postmagmatic stage Karasug fluorite-barite-siderite carbonatites were subjected to pneumatolytic hematitization, hydrothermal celestinization and silicification [1]. Apparently, if hematitization in minerals of carbonatites are formed is primary-secondary crystal-liquid inclusions with temperatures of homogenization $480^{\circ} \mathrm{C}-420^{\circ} \mathrm{C}$, and the hydrothermal end of the process is recorded in fluid inclusions homogenised within $380^{\circ} \mathrm{C}-250^{\circ} \mathrm{C}$ [3].

\section{Conclusions}

When trying to decipher the physico-chemical conditions of formation of fluorite-barite-siderite carbonatite in Karasug deposit, a number of issues raise, which are of general importance for understanding the genesis of ferrocarbonatite. Among them: 1) the salt carbonatite melt is an ionic liquid, and the release of minerals from it occurs as a result of ionic exchange reactions; 2 ) predominantly $\mathrm{Na}$-K-chloride composition of crystal-fluid inclusions can be pseudo-primary, and their chemical composition does not correspond to primary carbonatite melt, but corresponds to the residual brine-melt; 3) iron in the primary melt is predominantly in the chloride form; 4) sodium and potassium salts are also present in the primary melt, but are not fixed in the products of crystallization; 5) the predominance of sulfate over sulfide in the melt raises the question about the external source of oxygen and the mechanism of its penetration in highpressure magmatic system; 6 ) the mechanism for the removal of a large volume of residual $\mathrm{Na}$ and $\mathrm{K}$ chlorides from the crystallizing melt remains unclear.

High-temperature experiments in the system siderite-barite-fluorite \pm salts of alkaline metals are necessary to answer these and other issues. 


\section{References}

[1] Bolonin, A.V., Kaikova, T.M. and Komarnickiy, G.M. (1984) On the Nature of the Carbonatite Complex Iron-Fluorite-Barite-Rare Earths Deposit. Izvestia vuzov, Geology and Exploration, 3, 59-64.

[2] Nikiforov, A.V., Bolonin, A.V., Sugorakova, A.M., Popov, V.A. and Lykhin, D.A. (2005) Carbonatites of Central Tuva: Geological Structure, Mineral and Chemical Composition. Geology of Ore Deposits, 47, 326-345.

[3] Prokopyev, I.R., Borisenko, A.S., Borovikov, A.A. and Pavlova, G.G. (2016) Origin of REE-Rich Ferrocarbonatites in Southern Siberia (Russia): Implications Based on Melt and Fluid Inclusions. Mineralogy and Petrology, 110, 845-859. https://doi.org/10.1007/s00710-016-0449-Z

[4] Treiman, A.H. and Schedl, A. (1983) Properties of Carbonatite Magma and Processes in Carbonatite Magma Chambers. The Journal of Geology, 91, 437-447. https://doi.org/10.1086/628789

[5] Jones, A.P., Genge, M. and Carmody, L. (2013) Carbonate Melts and Carbonatites. Reviews in Mineralogy \& Geochemistry, 75, 289-322. https://doi.org/10.2138/rmg.2013.75.10

[6] Jones, A.P. and Wyllie, P.J. (1983) Low-Temperature Glass Quenched from a Synthetic, Rare Earth Carbonatite: Implications for the Origin of the Mountain Pass Deposit, California. Economic Geology, 78, 1721-1723. https://doi.org/10.2113/gsecongeo.78.8.1721

[7] Tagirov, B.R. and Korjinskiy, M.A. (2001) Speciation of $\mathrm{Fe}(\mathrm{II})$ in $\mathrm{H}_{2} \mathrm{O}-\mathrm{HCl}-\left(\mathrm{CO}_{2}\right)$ Fluid at $500-600^{\circ} \mathrm{C}$ and a Pressure of 2 kbar. Geochemistry, 9, 857-863. 